\title{
DIFFERING DEVELOPMENT PATHS OF SPATIAL INCOME INEQUALITIES AFTER THE POLITICAL TRANSITION - BY THE EXAMPLE OF HUNGARY AND ITS REGIONS
}

The debate about trends and changes is a topical issue today regarding the current financial and economic crisis. Hungary delimited seven NUTS-2 planning-statistical regions with the less developed Northern Great Plain region and the top ranking Western Transdanubia. The study deals with the developing path of spatial income inequalities with the methods of Hoover index and the logarithmic standard deviation. The decay and the growth of inequalities were significantly higher in the case of the underdeveloped territories. Developed areas faced a moderate increase concerning their inequalities and these microregions were able to attract new investments and restructure their economy.

Keywords: Hungary, income inequality, Kuznets-Williamson inverted-U hypothesis, spatial disparities, spatial pattern, transition economy

\section{Introduction}

The debate about trends and changes is a topical issue today regarding the current financial and economic crisis because regional development or decay always influences regional inequalities. The analysis of a former economic recession could illustrate the effects of regional development trends on the level and tendencies of spatial income inequalities.

In order to find evidence for the different paths of development, two characteristic territories of Hungary were involved in the study. In the light of the results for these regions and the international experiences, general conclusions might be drawn concerning the territorial effects of an economic recession and evaluation of the last more than two decades' processes can be completed as well.

The classical theory about the relationship between regional development and the level of spatial inequality derives from Simon Kuznets' hypothesis that represents this correlation as an inverted-U curve [1]. Williamson's study confirmed this hypothesis from a regional aspect as well [2]. According to this dual-hypothesis, the first period of regional growth is characterized by a low-

\footnotetext{
${ }^{1}$ C János Pénzes, Zoltán Bujdosó, Lóránt Dávid, Zsolt Radics, Gábor Kozma. 2014. Text.
}

level of inequalities. Rapid growth of inequalities occurs with the subsequent development, which reaches its peak after a certain period. The continuous regional growth causes the appearance of convergence influencing the accelerated decrease in regional inequalities. This trend of regional inequality forms a spectacular inverted-U curve.

The Kuznets-Williamson inverted-U hypothesis became the most important basis for several comparative studies that partly confirmed this theory, but some of them contradicted it [3]. Numerous questions arose concerning the trends after the convergence period [4] or the role of regional policy [5]. Increasing spatial income inequalities appeared in the second half of the 1980's due to globalization and the sectoral changes in the terciery sector [6]. The largest metropolitan areas are becoming the centres of managing and controlling the world economy, as a consequence of globalization. The new services (e.g. banking, financing, management sector) with high income-levels appear primarily in the largest cities generating increasing income inequalities again [7].

Economic recessions also have an impact on the spatial income pattern. Temporary economic recessions usually cause an increase in spatial income inequalities [8]. However, long-term transitional crises also have an important role in the increase and high-level stagnation of spatial in- 
come inequalities [9]. It can be assumed that similar economic shocks tend to trigger less rise in income inequalities in more developed areas, than in the poorer ones [8]. Disparities tend to increase during the short-term periods of rapid economic expansion and tend to decrease in the periods of slow economic growth [10].

According to the previously represented models and hypotheses, the waving of regional inequalities might be assumed [11]. The amplitude of waves becomes moderate in function of time (or with development), and the proportion of the population affected negatively by the inequalities is narrowing (according to a Hungarian author's László Lackó - hypothesis) [12]. Naturally, the extent of amplitudes depends on the seriousness and rapidity of the recession itself. The tendencies of transition economies are especially worth considering from this respect.

\section{The most characteristic spatial processes during the transition to a market economy}

Different analyses from the European Union can be summarized by the decreasing inter-country disparities with growing intra-country inequalities (sometimes with polarization), with other words Pan-European convergence accompanied by local divergence $[13,14]$. The Central-European countries - mostly post-socialist transition economies - became unique part of the development pattern of the European Union after their accession in 2004. Decreasing disparities were detected among these countries however, the inequalities significantly increased within them $[14,15]$.

Hungary and the post-socialist countries in Central Europe have a specific trend in the development of spatial inequalities. The political transition at the end of the 1980's and at the beginning of the 1990's caused the collapse of the former centrally controlled state economy. The more or less even distribution of the economy transformed due to privatization and new foreign direct investments (FDI). The transition to market economy resulted in the decay of economic sectors oriented to Eastern markets. As a matter of course, this process was accompanied by a significant rise in unemployment [16] and the formation of depressed territories mainly in the case of former centres of mining and heavy industry [17]. Rural areas had to face the shrinking of former socialist agriculture markets whose recession was serious as well [18].

Areas located close to the prosperous Western European economic centres and/or possessing competitive human resources or industrial features have undergone successful structural change [19]. At the same time, the crisis of the Eastern pe- ripheries deepened because of the lack of foreign capital, the missing infrastructure and unfavourable human resources. The Western territories and the largest towns - mainly the capital cities - are the winners of transition [20,21].

The mentioned basic territorial-economic changes caused a significant rise in spatial inequalities and the spatial pattern has become even more polarized. (inter alia [22, 23].

József Nemes Nagy modified the KuznetsWilliamson inverted-U hypothesis with special emphasis on the inequality processes of the post-socialist transition countries [24]. The period of socialism was characterised by an 'artificial' convergence process that collapsed at the time of the political and economic transition. The above mentioned events of the economic changes caused an enormous fall in the Gross Domestic Product (approximately 30 percent). The level of income inequality returned to the typical trend line of market economies, however, this phenomenon meant a dramatic change in the case of Hungary.

The most characteristic changes of the Hungarian spatial pattern after the political transition in 1989 can be summarized as follows:

- the strengthening role of the capital city, Budapest (this phenomenon was previously significant as well, however, as the result of the transition it has become more dominant);

- the emergence of the "West-East slope" (this spatial disparity was also an existing feature of the Hungarian development pattern);

- the increasing inequalities in micro level. [24].

The listed tendencies of regional disparities are not unique in Hungary - similar spatial pattern and development can be seen in the case of more Central European countries. For example, Slovakia (e.g. [25]) and Poland reflects similar spatial features however the latter one - due to its more balanced structure of settlement network - is characterised by the great city - rural area dichotomy $[26,27]$. It is important to emphasize that these dimensions of spatial disparities are not new symptoms [28], but these have become even more spectacular as the result of the political-social-economic transition processes.

The most important objective of the current study is to analyse the Hungarian trends of regional income inequality in order to draw the attention of some characteristic territorial features.

\section{Methodology}

The database and the analysis required to the examination were constructed and carried out using various methods. The most part of the availa- 


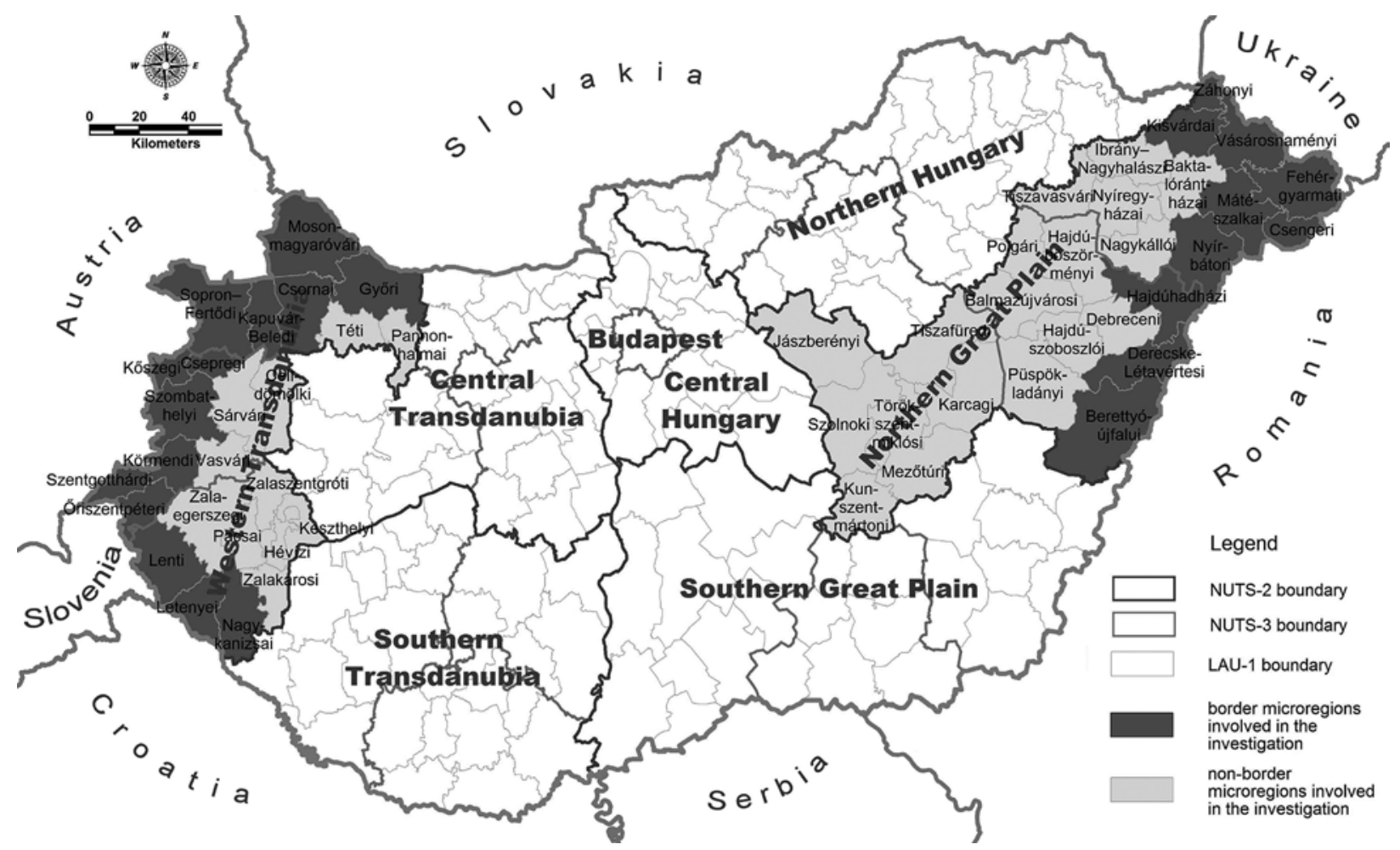

Fig. 1. The territorial units of Hungary and the investigated regions (own edition)

ble data comes from the publications of the KSH (Hungarian Central Statistical Office). Income in the current paper is expressed by the taxable income that was registered by the APEH (Hungarian Tax and Financial Control Administration that it is called National Tax and Customs Administration from 2010) and published by the KSH (Hungarian Central Statistical Office).

In order to attain our goals different methods were conducted during the research. Beside the analysis of the inequality trends, inequality factors in regional comparison also were used. The Hoover index and the logarithmic standard deviation are suitable methods in regional research we used them, as well. The study contains the methodology of analysis of inequality trends with the precipitousness of the linear regression line while the results are illustrated by maps and graphs.

\section{Results}

\section{Regional income processes in Hungary during the transition}

Hungary - according to the territorial statistic nomenclature of the European Union - delimited seven NUTS-2 planning-statistical regions on the basis of the historically existing NUTS-3 level of 19 counties and the capital city, Budapest. The LAU-1 level means the system of micro-regions built up by 175 units [29]. In the current paper, the emphasis is on the Northern Great Plain (in Hungarian: Észak-alföldi régió) and on the
Western Transdanubia (Nyugat-dunántúli régió) regions (Fig. 1).

The Hungarian regional income ${ }^{1}$ levels represent differing paths in the last more than two decades. These trends tend to form the so-called convergence clubs with the grouping of regions with similar income and development level while the distance between these groups are significant and often growing. The group of developed regions (including Central Hungary, Central and Western Transdanubia regions) is expressly separated; the other group of the regions (the Northern Great Plain region is among them) represented significantly lower values of per capita income. (Budapest is not included in the comparison due to its extremely high values - its income per capita exceeded 134.6 percent of the national average) (Fig. 2).

Most of the regions faced with decreasing income level in comparison with the Hungarian national average (that contained the income mass of Budapest as well) after the regime change in 1989

\footnotetext{
${ }^{1}$ Income in the current paper is expressed by the taxable income that was registered by the APEH (Hungarian Tax and Financial Control Administration that it is called National Tax and Customs Administration from 2010) and published by the KSH (Hungarian Central Statistical Office). Taxable income is built up by the tax returns of taxpayers, it contains approximately 38-40 percent of the total legal incomes however this income concept is most detailed from territorial point of view it is available on the LAU-2 (settlement) level.
} 


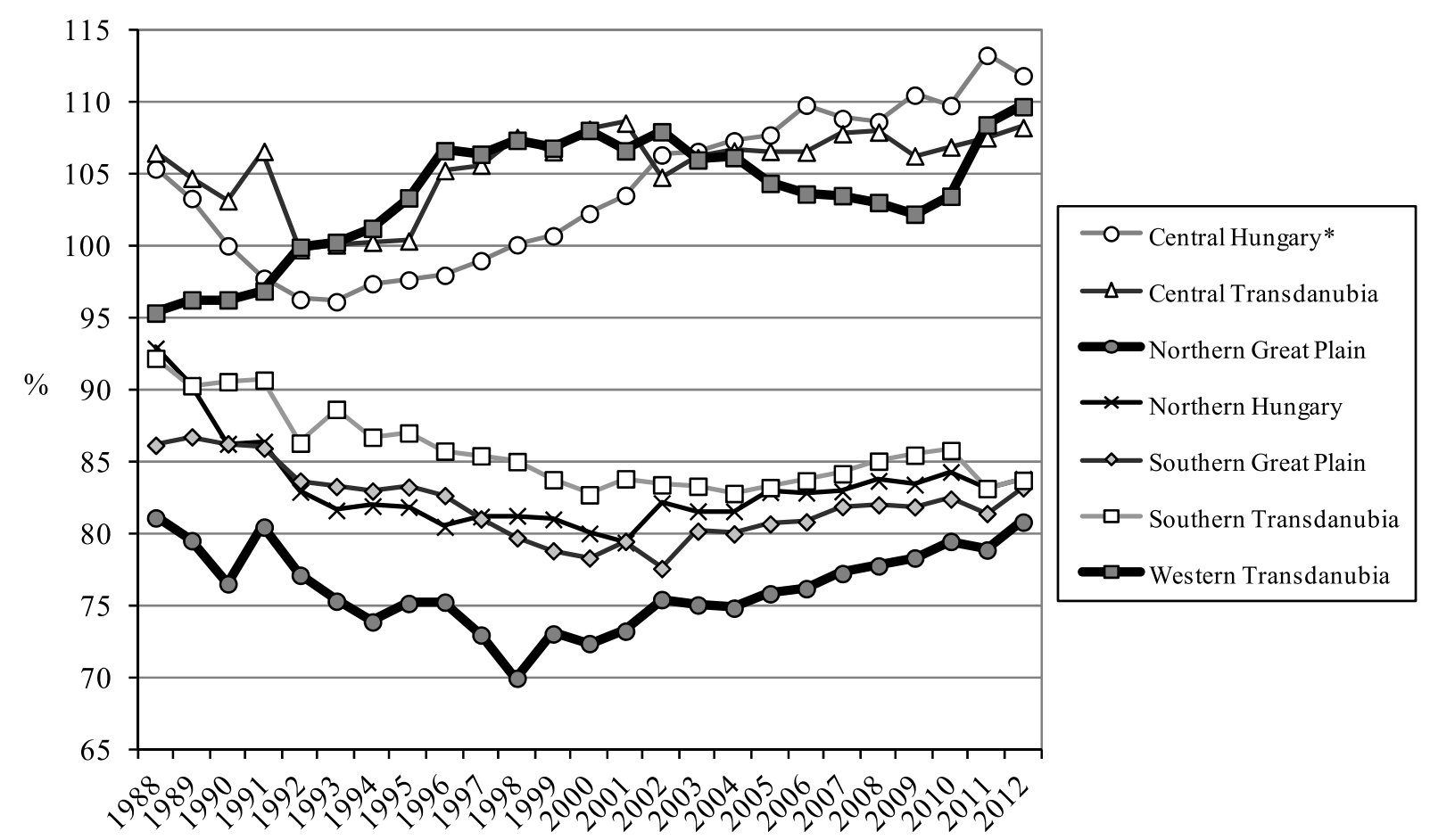

Fig. 2. The relative income per capita level of NUTS-2 regions in the percentage of the Hungarian national average, \% (calculated by the database of APEH-NAV and KSH) *without Budapest (own edition)

- the value of Budapest was growing rapidly at the same time. Some characteristic regional income trajectories can be detected. The Western Transdanubia region seemed to an exception because its income level was rapidly increased until the millennium and a slight shrinking arose during the first decade of 2000. The financial-economic crisis erupted in 2008 caused a decay similarly to the Central Transdanubia region (the economies of these regions are strongly related to the globalised world economy through their manufacturing industry - e.g. automotive industry, manufacture of electronic products). Central Hungary is basically influenced by Budapest due to it concentrates more than 22.6 percent of the national income (its weight tends to decrease in the last one and half decade). As the result of the suburbanization, most part of the Central Hungarian settlements has migration gain from the direction of Budapest and increasing income level can be detected thank to the wealthy occupants and families moving there. The income tendency clearly shows this process.

The group of less developed regions faced with dynamically decreasing income level until the millennium and a moderate closing up has appeared since then. This process broke due to the modification of the taxation system by 2011, however the curves corrected in 2012.

\section{Income inequality trends of regions}

As part of the analysis of the inequality trends - it is important to introduce the applied ine- quality indicators. There are more than 50 different inequality indicators [30, 31] however only two of them were selected. The Hoover index and the logarithmic standard deviation are often used ones on the field of economics, sociology and regional science as well. This selection was supported by a Hungarian study [32].

$$
h=\frac{\sum_{i=1}^{n}\left|x_{i}-y_{i}\right|}{2} \text {. }
$$

The equation of Hoover index $(h)$, where $x_{i}$ and $y_{i}$ are two variables and $\Sigma x_{i}=100 \% ; \Sigma y_{i}=100 \%$. The Hoover index is known as Robin Hood index in the case of the comparison of income and population distributions - this form will be used in this paper.

$$
V=100 \sqrt{\frac{\sum_{i=1}^{n}\left(\log \frac{y_{i}}{\bar{y}}\right)^{2} f_{i}}{\sum_{i=1}^{n} f_{i}}} .
$$

The equation of the weighted form of mean logarithmic variation $(V)$, where $y_{i}$ is the income per capita of a spatial unit; $\bar{y}$ is the weighted mean of income within the investigated territory; $f_{i}$ is the weight - in this case the number of population.

These inequality measures are appropriate to express the most important characteristics of income disparities. According to the empir- 


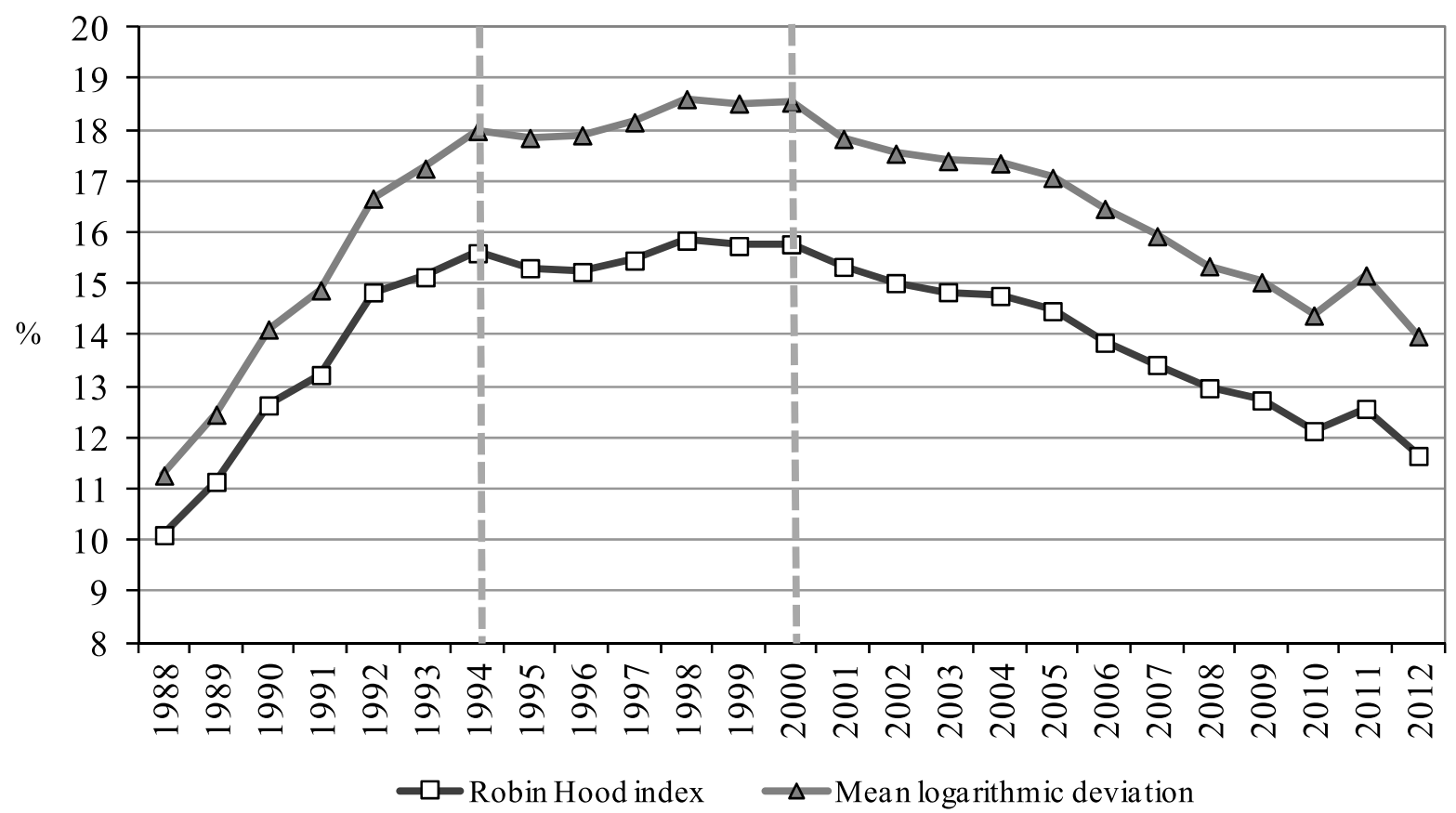

Fig. 3. The development of income inequality on the level of settlements calculated by the Robin Hood index and the logarithmic standard deviation, \% (calculated by the database of APEH-NAV and KSH) (own edition)

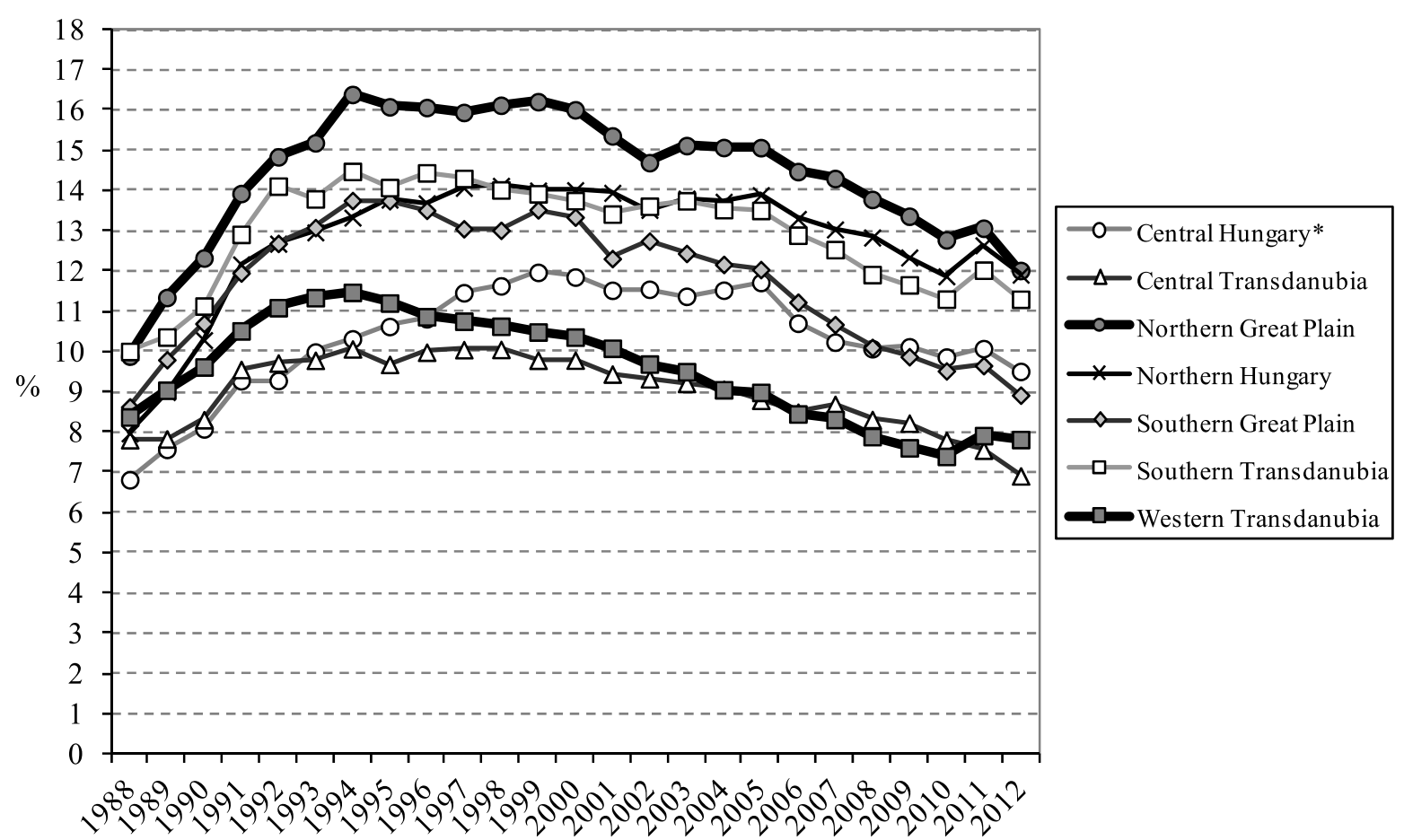

Fig. 4. The development of intra-regional income inequalities in the NUTS-2 regions calculated by the Hoover index, \% (calculated by the database of APEH-NAV and KSH) * without Budapest (own edition)

ical findings, the Robin Hood index and the often used Gini coefficient are in close relationship (through the Lorenz curve) and their tendencies almost perfectly parallel to each other (for this reason only the former one is applied in the current analysis).

The national trends of income inequalities between 1988 (the first publication of taxable income database after the introduction of the per- sonal income tax) and 2012 are illustrated separately (Fig. 3), due to the influence of the territorial units' aggregation level and the number of localities on the result of the inequality calculations [33, 34].

The inequality trends were calculated on the level of settlements (more than 3,000 localities) and the curves can be divided into three stages. In the first stage, a dynamic divergence deter- 


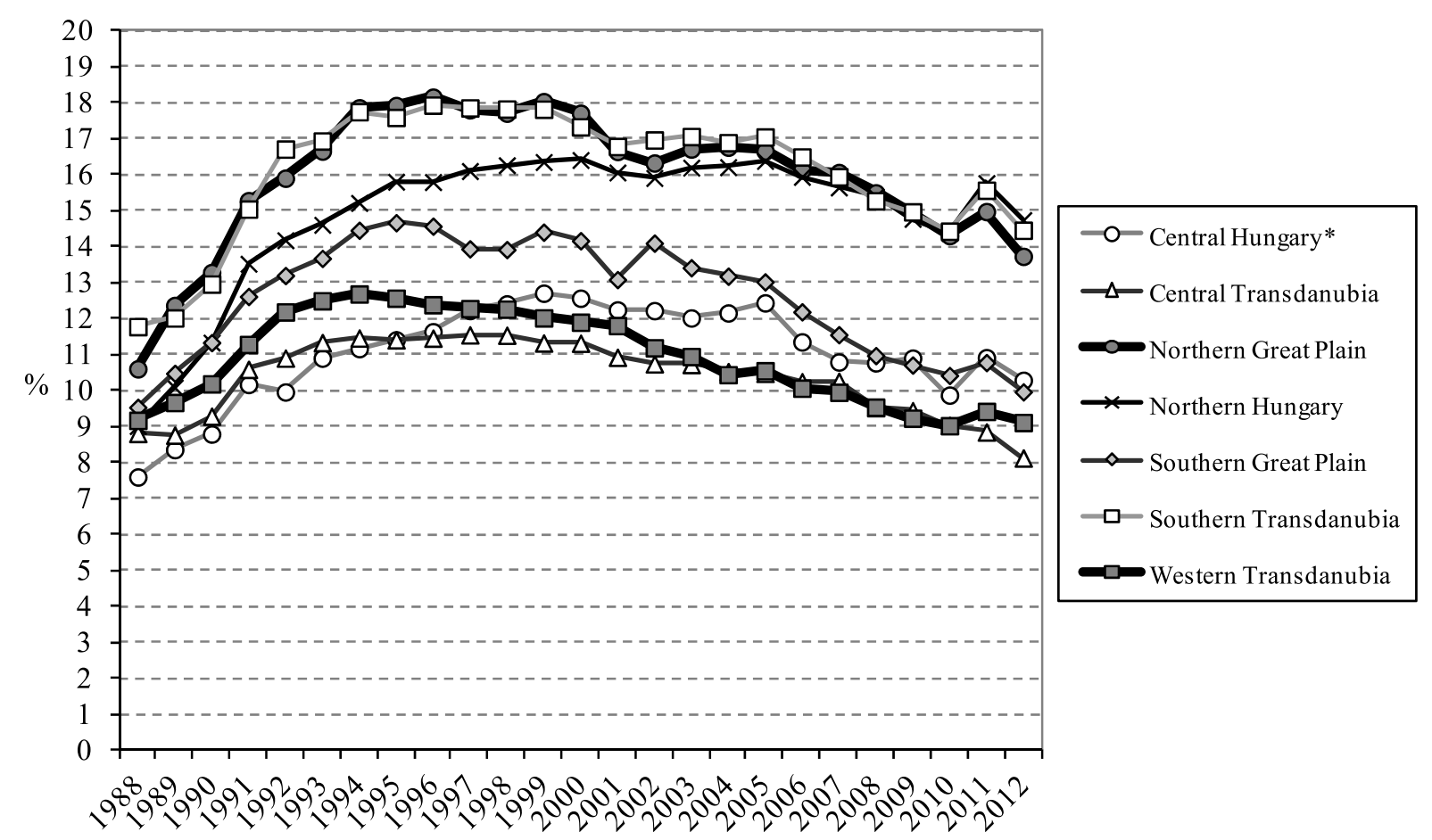

Fig. 5. The development of intra-regional income inequalities in the NUTS-2 regions calculated by the logarithmic standard deviation, \% (calculated by the database of APEH-NAV and KSH) * without Budapest (own edition)

mined the spatial income tendencies until the mid 1990's. From the mid 1990's until the millennium, a high level stagnation could be detected and a moderate convergence has appeared since 2000. However, the trend has shown a spectacular break by 2011 - as it was also seen in the case of the income per capita - and it has corrected by the last year. The modification of the taxation system in 2010 caused a temporary polarization among the taxpayers that had territorial consequences as well (due to the extension and unification of the tax classes). The distance grew between the national average and both the settlements with extremely high and low values. The effect was more spectacular in the case of those regions that have mosaic-like pattern of network of settlements - supported by the results of the calculations carried out for the NUTS-2 regions. (Fig. 4 and 5).

The intra-regional income inequalities more or less differ from each other and from the national trends. For example, the convergence stage has become clearly seen from the mid 2000's in the case of Central Hungary - due to the dragging 'intra-regional' polarization caused by the suburbanization in the surroundings of Budapest. Or, the stagnation period is not represented by the Western Transdanubia region.

According to the tendencies of the whole investigated period, two characteristic regions were chosen in order to analyse the intra-regional tendencies of spatial income inequalities.

\section{Characteristic income tendencies in the investi- gated regions}

The Northern Great Plain region and the Western Transdanubia region represent the two poles of the Hungarian economic transition and this is the reason why these regions are often involved in comparative studies. (e.g. [35])

The development level of these regions represented significant differences prior to the political transition as well, but the distance between their social-economic indicators became even more spectacular in the 1990's. (Table 1)

Following the political transition in 1989, the geopolitical situation of Western-Hungary became attractive to FDI. The proximity of prosperous Western-European markets, the relatively developed infrastructure, the qualified human resources and the existing tradition of production (mainly the processing- and automotive industry) were the most vital factors. These investments played important role in the successful restructuring of the economy. The economic recession was not so drastic than in the North-eastern parts of Hungary. The fall in the number employed and the rise in the unemployed was moderate in comparison with the Northern Great Plain region, where the recession seemed to be long-term and acute.

The limited amount of FDI targeted the competitive parts of the remaining economy, as a result of privatization after the political transition. Few productive new investments were realised in the Eastern parts of the country and these invest- 
Table 1

The most important indicators for the investigated regions and their changes (calculated by the data from KSH)

\begin{tabular}{|l|c|c|c|}
\hline \multicolumn{1}{|c|}{ Indicators } & Year & Northern Great Plain & Western Transdanubia \\
\hline Number of population, head & in 2013 & $1,491,659$ & 985,279 \\
\hline \multirow{2}{*}{ Average migration balance per 1000 inhabitants } & $\begin{array}{c}\text { between } \\
2001-2012\end{array}$ & -2.8 & +3.4 \\
\hline \multirow{2}{*}{ GDP per capita in percentage of the national average } & in 1975 & $77.0 \%$ & $95.8 \%$ \\
\cline { 2 - 4 } & in 2011 & $64.7 \%$ & $102.6 \%$ \\
\hline \multirow{2}{*}{$\begin{array}{l}\text { Employment rate in percentage of the national } \\
\text { average }\end{array}$} & in 1990 & $93.2 \%$ & $102.4 \%$ \\
\cline { 2 - 4 } $\begin{array}{l}\text { Per capita income in percentage of the national } \\
\text { average }\end{array}$ & in 2011 & $89.3 \%$ & $109.4 \%$ \\
\hline FDI per capita in percentage of the national average & in 2012 & $81.1 \%$ & $95.4 \%$ \\
\hline Rate of registered unemployment & in 2010 & $80.9 \%$ & $109.7 \%$ \\
\hline
\end{tabular}

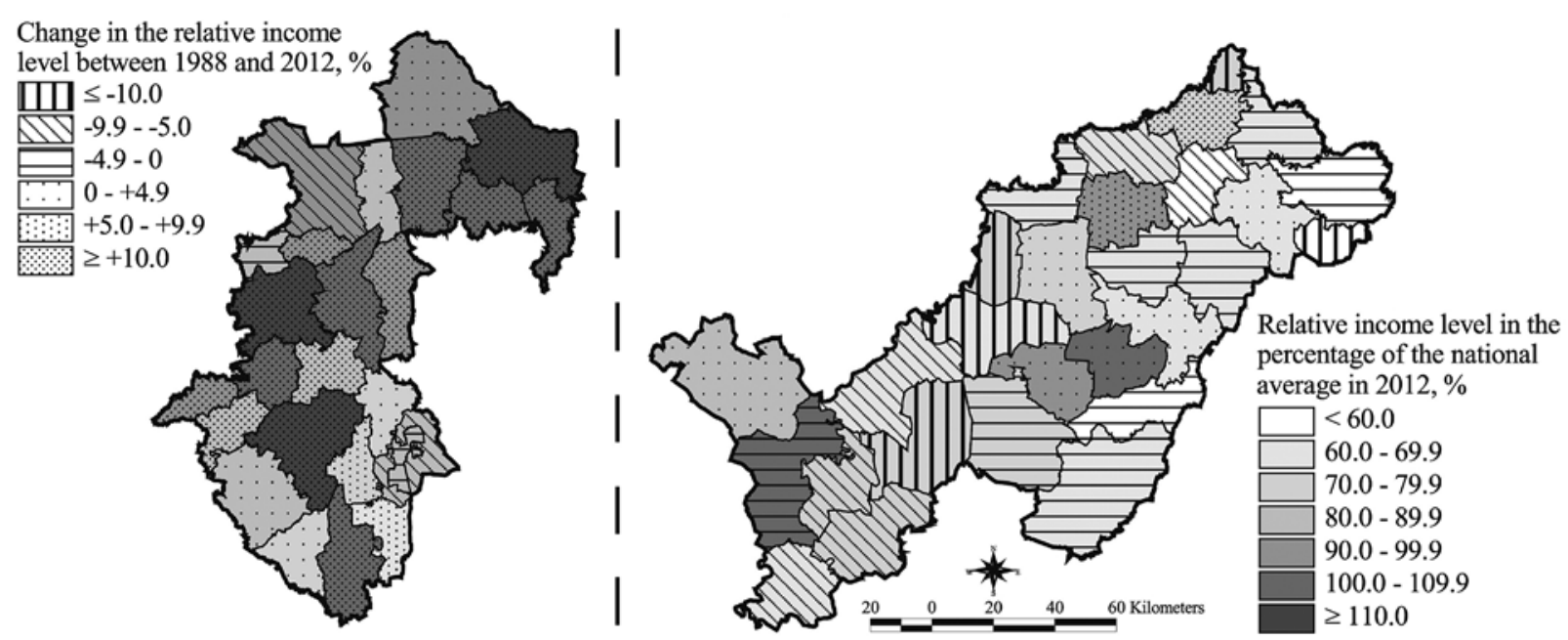

Fig. 6. The relative income level in 2012 (in the percentage of the national average) and the change in the relative income level between 1988 and 2012 (\%) in the micro-regions of Western Transdanubia (left) and Northern Great Plain region (right) (calculated by the database from the APEH-NAV and KSH) (own edition)

ments show a considerable concentration in the largest towns of the area.

The above mentioned processes had significant effects on the spatial income pattern that resulted in different characteristics in the investigated regions. (Figure 6) Most of the LAU-1 micro-regions of the Northern Great Plain region are characterised by low level of income per capita compared to the national average. Only the micro-regions of two county centres - Szolnok and Debrecen - had higher income per capita than the national value in 2012. However, extremely low level of income was also been detected in this region; the value of the Baktalórántházai, Fehérgyarmati, Csengeri and Derecske-Létavértesi micro-regions did not reach the 60 percent of the national average (for the location of the mentioned places check the Figure 1).

The income values are unambiguously higher in the case of the Western Transdanubian micro-regions. 9 micro-regions were characterised by above average income per capita level in 2012 . The lowest values in this region can be found on the southern part - in the case of the Pacsai (63.7 percent) and Zalakarosi (73.9 percent) micro-regions in national comparison.

The dynamics of the relative income levels during the whole period can also be investigated by the Figure 6. The income level in the Northern Great Plain region was originally low in the basis year and the underdeveloped territories suffered a serious drop in their income levels during the investigated period (for details and the most important reasons see [36]) Only a few micro-regions showed growth in their relative income levels (the Kisvárdai, the Nyíregyházai, the Jászberényi, the Hajdúböszörményi, the Debreceni, the Hajdúhadházi, the Mátészalkai and the Hajdúszoboszlói micro-regions). In spite of this fact, the largest parts of Western Transdanubia avoided the large decrease in income levels that tended to be higher than the national average, 

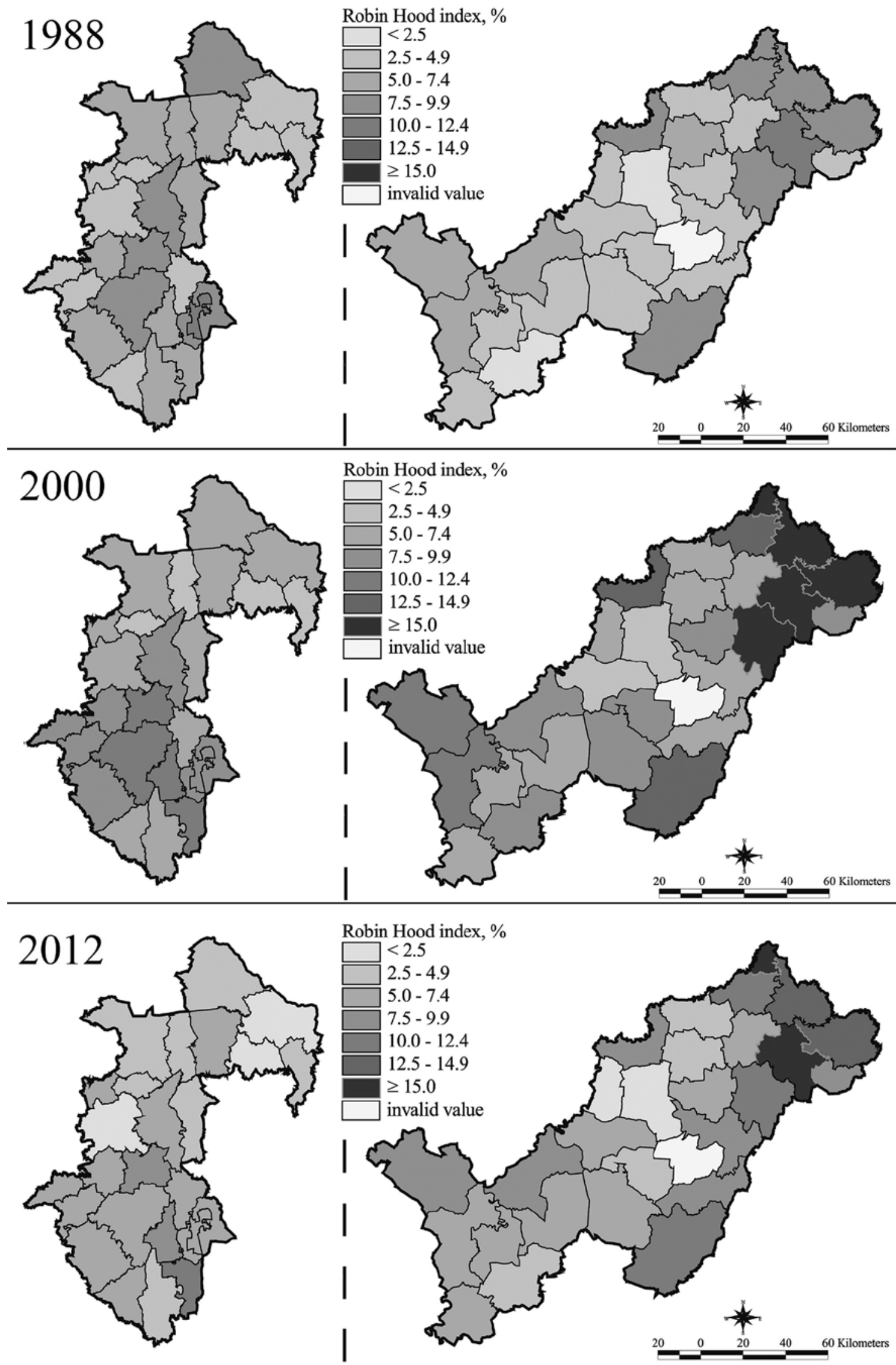

Fig. 7. The values of spatial income inequality measured by the Robin Hood index in the micro-regions of Western Transdanubia (left) and Northern Great Plain region (right) in the given years, \% (calculated by the database from the APEH-NAV and KSH) (OWn edition) 
mainly in the case of the northern part of the region (decrease can be detected in the case of the Sopron-Fertődi, the Keszthelyi, the Hévízi and the Kőszegi micro-regions).

The favourable situation of the Western Transdanubia region can be summarized in the followings (some of these general issues were mentioned earlier); this region had a more developed infrastructure also at the time of the transition and traditions in manufacturing (mainly in manufacture of machinery), and, last but not least, which were closer to the central areas of Europe, became the main target area of foreign direct investments. The most emblematic and considerable new investments are these - Audi in Győr; General Motors in Szentgotthárd; and different equipment manufacturers - e.g. Delphi, LuK in Szombathely; Flextronics in Zalaegerszeg. Furthermore, micro-regions with tourism assets (e.g. Öriszentpéter and Pannonhalmai micro-regions, and in given years the Hévízi and Keszthelyi micro-regions), favourable location (e.g. Téti micro-region) and those with a considerable number of workforces commuting out (e.g. Pannonhalmai and Téti micro-region) got into a better position as well. The tourism and service sector of the Kőszegi and Sopron-Fertődi micro-regions significantly relates to the Austrian demands from the other side of the border and the ratio of cross-border commuting workers are also high (however their income mass are not often registered in the applied database - this is one reason for the relative weakness of these micro-regions).

The Northern Great Plain attracted really limited amount of new foreign investments (Table 1) and these were mainly concentrated in the county-seats (National Instruments and IT Services in Debrecen, LEGO in Nyíregyháza, Eagle Ottawa in Szolnok), however some towns - according to their traditions of production - were target of foreign investments (e.g. Electrolux and Samsung in the Jászberényi micro-region and Unilever in the Nyírbátori micro-regions).

\section{The pattern of intra-regional income inequali- ties in the investigated regions}

The intra-regional spatial income inequalities of LAU-1 micro-regions were also included into the current investigation. It was regarded to illustrate the spatial pattern of inequalities calculated by the Robin Hood index. The development of inequality was reasonable to take place by the illustrated three stages because it is clearly seen that the level of disparities were moderate in the first year that rapidly grew during the 1990's, however the increase was significantly higher in the case of the Northern Great Plain (Figure 7). The maximum values of inequality indicators in the Western Transdanubian micro-regions were not considerable in national comparison.

The culmination of the inequality curves occurred by the end of the 1990's in the case of the Northern Great Plain region, but the western territories reached their maximum values earlier; in the first part of this decade. However, exceptions can be found in both regions, the considerable difference between them are clearly seen. After the millennium, the level of inequalities tended to decrease, but outstanding high values are typical along the Hungarian-Ukrainian and along a given section of the Hungarian-Romanian border in the Northern Great Plain region. The Mátészalkai, the Záhonyi, the Fehérgyarmati, the Vásárosnaményi, the Nyírbátori and the Kisvárdai micro-regions were characterised by the greatest inequalities. (The Debreceni micro-region contains only two settlements, so the calculations cannot be regarded as valid.)

The most important reason for this phenomenon is the relevance of the Kuznets-Williamson hypothesis that tends to be valid by these cases. Németh, Nándor and Kiss, János Péter proved the existence of the inverted-U relationship between the income level and the level of intra-regional inequalities in the case of Hungary by an empirical analysis [36].

In order to represent the current trends of inequalities, a trend-analysis was carried out (similar to the referred study; [32]) (Figure 8). The methodology was based on the results of the two represented inequality calculations (namely the Robin Hood index and the logarithmic standard deviation). The precipitousness of the linear regression line fitted into the curve of inequality values gave the direction of the tendency from $2000(+/-0.05$ in either of the indexes meant divergence or convergence. If both calculations provided a value between +0.05 and -0.05 , that case was categorised as stagnation. Only one micro-region (Törökszentmiklósi micro-region) produced inconsistent results. The Robin Hood index showed convergence influenced by the growing level of income, at the same time the polarized values (including one of the poorest villages in Hungary; Tiszabó) caused the increasing level of logarithmic standard deviation.

Convergence was dominant in the Western Transdanubia region (except for the Pacsai and Zalakarosi micro-regions) between 2000 and 2012. Most part of the Northern Great Plain can also be described by decreasing trend of inequalities however, five micro-regions (Baktalórántházai, 


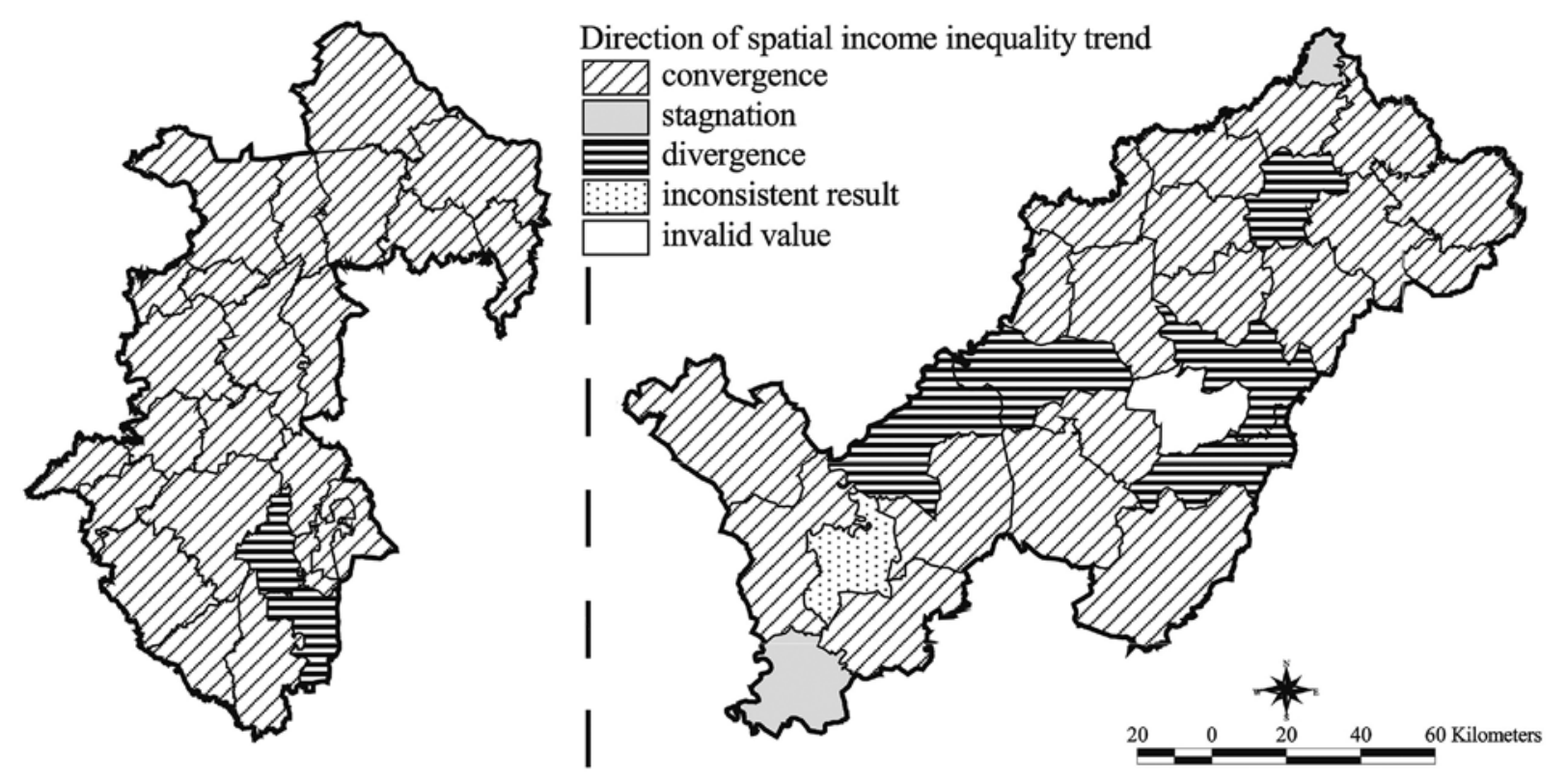

Fig. 8. The trends of income inequality after the millennium, measured by different inequality methods in the micro-regions of the investigated regions (calculated by the database from the APEH-NAV and KSH) (own edition)

Balmazújvárosi, Derecske-Létavértesi, Hajdúhadházi and Tiszafüredi) represented divergence and two more (Kunszentmártoni and Záhonyi) showed stagnation. With a quick overview, the most interesting and adequate representatives of the tendencies are illustrated as follows.

The micro-regions that contain a large town with its sphere of influence are generally characterised by decreasing inequality values (at least in the last decade) due to the phenomenon of suburbanization because the strong spatial concentration of incomes starts to reduce. Debrecen is an exception because its commuter's belt was separated into the neighbouring micro-regions Derecske-Létavértesi and Hajdúhadházi micro-regions where divergence was detected after 2000. The distribution of income tends to become more uneven within these territories influenced by the growing income level of settlements located close to the centre.

A rapid growth of income inequality occurred in the Szentgotthárdi micro-region after the General Motors automotive investment. Divergence was generated by the income polarization that emerged as the result of the growing number of local job opportunities in the centre. However, this increase of inequality was replaced by convergence a few years later. The extending commuter's belt and the connected enterprises deconcentrated the personal incomes. A similar, but not so expressed process is seen in the Jászberényi micro-region in the Western part of the Northern Great Plain region (as a result of the investments of Electrolux ans Samsung). This means that suc- cessful structural transition has an important role in territorial convergence in the medium term.

It is important to emphasize that convergence cannot be evaluated only as an absolutely positive process. The decreasing level of income inequality might be the consequence of the decay of the economic centre of a territory, as it can be observed in the Tiszavasvári micro-region in the Northern Great Plain region. The drastic cut-back in the largest local pharmaceutical factory caused a serious fall in the income level of the centre town itself that caused intra-regional convergence.

High level of income inequalities, divergence, or stagnation and convergence can be detected in the least developed micro-regions in the last few years. The processes during the transition were dominated by one or two larger towns that could maintain their level of employment and income while their surroundings faced with drastic reduce in the number of local employment and in the number of commuters as well. This pattern was really characteristic in the case of the most backward areas. Nowadays, a slight convergence process tends to be typical however, some of these micro-regions still represent the illustrated symptoms.

\section{Conclusions}

The results of the calculations indicate a spectacular growth in spatial income inequalities after the political transition following the economic recession. The decay and the growth of inequalities were significantly higher in the case of the underdeveloped territories in the Northern Great Plain 
region. Developed areas faced a moderate increase concerning their inequalities and these microregions were able to attract new investments and restructure their economy. These results reflect Kuznets-Williamson's hypothesis and the mentioned theories about the behavior of income ine- qualities. Lackó's theory is also important to take into consideration. The possible effect of the current financial and economic crisis on spatial processes and income inequalities might be modeled from this point of view.

This research was supported by the European Union and the State of Hungary, co-financed by the European Social Fund in the framework of TÁMOP-4.2.4.A/ 2-11/1-2012-0001 "National Excellence Program".

\section{References}

1. Kuznets S. (1955). Economic Growth and Income Inequality, The American Economic Review, 45.1. 1-28.

2. Williamson J. G. (1965). Regional Inequality and the Process of National Development: A Description of the Patterns, Economic Development and Cultural Change 13.4. Part II (July 1965). Supplement.

3. Gyuris F. (2011). A Williamson-hipotézis. Egy koncepció tartalma, kritikája és utóélete (The Williamson hypothesis. The content, criticism and afterlife of a concept). Tér és Társadalom (Space and Sociaety), 2, 3-28.

4. Amos O. (1988). Unbalanced regional growth and regional income inequality in the later stages of development. Regional Science and Urban Economics, 18.4, 549-566.

5. Deutsch J., Silber J. P. (2004). Measuring the Impact of Various Income Sources on the Link between Inequality and Development: Implications for the Kuznets Curve, Review of Development Economics, 8.1, 110-127.

6. Fan C. C., Casetti E. (1994). The spatial and temporal dynamics of US regional income inequality, 1950-1989. The Annals of Regional Science, 28. 2, 177-196.

7. List J. A., Gallet C. A. (1999). The Kuznets Curve: What Happens After the Inverted-U? Review of Development Economics, 3.2, 200-206.

8. Barrios C., Strobl E. (2009). The dynamics of regional inequalities. Regional Science and Urban Economics, 39.5, 575-591.

9. Petrakos G. (2001). Patterns of Regional Inequality of Transition Economies. European Planning Studies, 9.3, 359-383.

10. Petrakos G., Rodríguez-Pose A., Rovolis A. (2003). Growth, Integration and Regional Inequality in Europe. Paper presented at the 43rd Congress of the European Regional Science Association (ERSA). Jyväskylä. Available at: http://ideas.repec.org/p/wiw/ wiwrsa/ersa03p46.html (downloaded: 30.06.2011).

11. Nemes Nagy J. (2005). Fordulatra várva - a regionális egyenlötlenségek hullámai (Waiting for the turn — the waves of regional inequalities). in: Z. Dövényi, F. Schweitzer (Eds.), A földrajz dimenziói (The dimensions of geography) (eds..), MTA FKI, Budapest, 141-158.

12. Lackó L. (1988). Területi fejlődés, politika, tervezés (Regional development, politics, planning). Akadémiai Publisher, Budapest.

13. Martin P. (1998). Can Regional Policies Affect Growth and Geography in Europe? The World Economy, 6, 757-774.

14. Paas T., Schlitte F. (2006). Regional income inequality and convergence processes in the EU-25. Paper presented at the 46th Congress of the European Regional Science Association (ERSA), Volos.

15. Ezcurra R., Pascual P., Rapún M. (2007). The Dynamics of Regional Disparities in Central and Eastern Europe during Transition. European Planning Studies, 15.10, 1397-1421.

16. Keane M. P., Prasad E. S. (2006). Changes in the structure of earnings during the Polish transition. Journal of Development Economics, 80, 389-427.

17. Heidenreich M. (2003). Regional Inequalities in the Enlarged Europe. Journal of European Social Policy, 13.4, 313-333.

18. Gorzelak G. (1996). The Regional Dimension of Transformation in Central Europe. Regional Policy and Development 10. Regional Studies Association, London: Jessica Kingsley Publishers.

19. Nemes Nagy J., Tagai G. (2011). Regional inequalities and the determination of spatial structure. Regional Statistics (Special Issue of the Területi Statisztika journal), 1, 15-28.

20. Fedorov L. (2002). Regional Inequality and Regional Polarization in Russia, 1990-99. World Development, 30. 3 , $443-456$.

21. Kislitsyna O. (2003). Income Inequality in Russia during Transition. How Can It Be Explained? Economics Education and Research Consortium, Working Paper Series. Moscow, $51 \mathrm{p}$.

22. Szabó P. (2003). Regional Development Disparities in the European Union. in: Á. Jakobi (Ed.), Frontiers of Geography, Eötvös Loránd University, Budapest-Heidelberg, 109-119.

23. Abrhám J. (2008). Rural development and regional disparities of the new EU Member States, Agricultural Economics, 57. 6, 288-296.

24. Nemes Nagy J. (2003). Geography and Spatial Modelling: Regional Income Inequalities in Hungary. in: Jakobi, Á. (Ed.) Frontiers of Geography, Budapest. ELTE Eötvös Publisher.

25. Halás M., Hurbánek P. (2006). Identifikácia a klasifikácia periférnych regiónov (pokus o syntézu). In: E. Džupinová et al. (Eds.): Periférnost' a priestorová polarizácia na území Slovenska, Geo-grafika, Bratislava, 109-136.

26. Gorzelak G. (2006). Poland's Regional Policy and Disparities in the Polish Space. Studia Regionalne i Lokalne. Special Issue, 39-74.

27. Churski P. (2010). Problem areas in Polish regional policy. Moravian Geographical Reports, 18.2, 23-35.

28. Fuchs R. J., Demko G. J. (1979). Geographic inequality under socialism. Annals of the Association of American Geographers, 69, 2, 304-318. 
29. Bujdosó Z., Pénzes J. (2012). The spatial aspects and distribution of the touristic development resources in the border microregions of Hungary, in: Zs. Radics, J. Pénzes (Eds.), Roma population on the peripheries of the Visegrad countries spatial trends and social challenges, Debrecen, 226-240.

30. Coulter P. B. (1989). Measuring inequality. A methodological handbook. West view Press, London.

31. Dávid L., Baros Z. (2007). A possible use of indicators for sustainable development in tourism. Anatolia: an international journal of tourism and hospitality research, 18.2, 349-355.

32. Németh N., Kiss J. P. (2007). Megyéink és kistérségeink belső jövedelmi tagoltsága (Intra-regional income disparities of the counties and micro-regions). Területi Statisztika, 1, 20-45.

33. Major K., Nemes Nagy J. (1996). Területi jövedelem-egyenlőtlenségek a kilencvenes években (Spatial income inequalities in the 1990's). Statisztikai Szemle, 6, 397-421.

34. Dusek T. (2004). A területi elemzések alapjai (The principles of regional analyses). Regionális Tudományi Tanulmányok 10. ELTE Regionális Földrajzi Tanszék - MTA ELTE Regionális Tudományi Kutatócsoport, Budapest.

35. Kozma G. (2008). Characteristic Features of the Economic Management of Local Authorities in the Western and the Eastern Border Areas of Hungary. in: I. Süli-Zakar (Ed.) Neighbours and Partners - On the two sides of the border, Kossuth Egyetemi Kiadó, Debrecen, 19-26.

36. Pénzes J. (2012). Changes in the Spatial Income Structure of North-eastern Hungary After the Change of Regime. Regional Statistics (Journal of the Hungarian Central Statistical Office). 52. Special number, 90-107.

\section{Information about the authors}

János Pénzes (Debrecen, Hungary) — PhD, Assistant Professor, Department of Social Geography and Regional Development Planning, University of Debrecen (Egyetem tér 1, Debrecen HU-4032, Hungary, e-mail: penzes.janos@science.unideb.hu).

Zoltán Bujdosó (Gyöngyös, Hungary) - PhD, College Professor, Institute of Tourism, Regional Development and Foreign Languages, Károly Róbert University College (Mátrai út 36, Gyöngyös HU-3200, Hungary, e-mail: zbujdoso@karolyrobert.hu).

Lóránt Dávid (Gyöngyös, Hungary) — PhD, College Professor, Institute of Tourism, Regional Development and Foreign Languages, Károly Róbert University College (Mátrai út 36, Gyöngyös HU-3200, Hungary, e-mail: davidlo@karolyrobert.hu).

Zsolt Radics (Debrecen, Hungary) — PhD, Assistant Professor, Department of Social Geography and Regional Development Planning, University of Debrecen (Egyetem tér 1, Debrecen HU-4032, Hungary, e-mail: radics.zsolt@science.unideb.hu).

Gábor Kozma (Debrecen, Hungary) - PhD, Associate Professor, Department of Social Geography and Regional Development Planning, University of Debrecen (Egyetem tér 1, Debrecen HU-4032, Hungary, e-mail: kozma.gabor@science.unideb.hu). 